\title{
Quality Standardization and Nephroprotective Effect of Garcinia pedunculata Roxb. Fruit rind
}

\author{
Ravi Mundugaru1, Senthil Kumar Sivanesan², Padmaja Udaykumar, Febin Joy4, Sunil Kumar Koppala \\ Narayana $^{5^{*}}$, Lekshmi Rajakrishnan ${ }^{6}$, Al Farhan Ahmed Abdullah Bin Hamad7, Thomas Jacob ${ }^{7}$, \\ Rajakrishnan Rajagopal ${ }^{7}$, Sameh Mohammed Hisham ${ }^{7}$
}

\begin{abstract}
${ }^{1}$ Department of Pharmacology, SDM Centre for Research in Ayurveda and Allied Sciences, Udupi, INDIA.
${ }^{2}$ Department of Research and Development, Saveetha University, Thandalam, Chennai, INDIA.

${ }^{3}$ Department of Pharmacology, Father Muller Medical College, Mangalore,INDIA.

${ }^{4}$ Department of Dravyaguna, Muniyal Institute of Ayurveda Medical Sciences, Manipal, INDIA.

${ }^{5}$ Department of Pharmacognosy, SDM Centre for Research in Ayurveda and Allied Sciences, Udupi, INDIA. Current: Department of Pharmacognosy, Siddha Central Research Institute, Arumbakkam, Chennai, INDIA.

${ }^{6}$ Department of Botany and Biotechnology, MSM College, Kayamkulam, Kerala, INDIA.

${ }^{7}$ Department of Botany and Microbiology, College of Science, King Saud University, P.O. Box 2455, Riyadh, SAUDI ARABIA.
\end{abstract}

\begin{abstract}
Fruit rind of Garcinia pedunculata is one of the important medicinal plant and a condiment used in Indian kitchen. In spite of many medicinal properties ascribed to this species, less of pharmacological studies are carried out on this species. The objective of present study was to determine the quality standards of the fruit rind followed by evaluation of nephroprotective activity of aqueous extract in cisplatin induced nephrotoxicity. Macromicroscopic, physico-chemical, preliminary phytochemical and HPTLC studies were carried out following pharmacopoeial procedures. On $7^{\text {th }}$ days an hour after treatment with group specific drugs, cisplatin $20 \mathrm{mg} / \mathrm{kg}$ was injected intraperitonially to all groups except normal control mice. Nephrotoxicity was assessed by serum biochemical, antioxidant and histological changes in kidney after $72 \mathrm{~h}$ of cisplatin injection. Pharmacopoeial tests revealed authenticity and quality indicating standards for the fruit rind. Single intraperitonial injection of cisplatin significantly elevated serum urea, creatinine and lipid peroxidation in kidney tissue compared to the control group. The drug has exhibited necrotic changes in the tubular epithelium, edematous changes in the interstitial tissue and focal cell infiltration. These changes were significantly reduced with AFGP administration and considerably reversed the histological changes caused by cisplatin injection.

Key words: Antioxidant, Cisplatin, Nephroprotective, Serum Creatinine, Quality Standards.
\end{abstract}

\section{INTRODUCTION}

Garcinia pedunculata Roxb., Fam. Clusiaceae is a tree common in dense forests of NorthEast India and Andaman Nicobar Islands. The dried rind of the mature but not fully ripen fruits (FRGP) has high medicinal value and used in diet of tribes of Assam and North-Eastern states of India. ${ }^{1}$ It is used in various ailments such as fever, cough, bronchitis, asthma, rheumatoid arthritis, obesity and used as a cardiotonic drug. ${ }^{2}$ The phytochemical analysis FRGP has shown phytochemicals such as pedunculol, garcinol, cambogin $^{3}$ and (-)-hydroxyl citric acid. ${ }^{4}$ Hexane and chloroform extracts of FRGP showed antioxidant activity, free radical scavenging activity and strong antimutagenicity, hexane extract being more active than chloroform. ${ }^{3}$ The chloroform and hexane extract of FRGP showed MIC on growth of Aspergillus flavus at 3000 and 4000 ppm respectively. ${ }^{2}$ FRGP is reported to have antibacterial, ${ }^{5}$ hepatoprotective, ${ }^{6}$ antiinflammatory ${ }^{7}$ and cardio protective activities. ${ }^{8}$ Cisplatin is a platinum coordinated cytotoxic drug which is widely used as a chemotherapeutic agent for metastatic testicular, ovarian carcinoma and in many other solid tumors.' Despite of its high
Submission Date: 30-11-2016; Revision Date: 31-03-2017; Accepted Date: 13-07-2017

DOI: 10.5530/ijper.51.4.105 Correspondence: Dr KN Sunil Kumar, Research Officer, Department of Pharmacognosy, Siddha Central Research Institute, Arumbakkam, Chennai, 600106. INDIA. Mob: +917406111071. E-mail: sunilkumarnarayanan@gmail.com

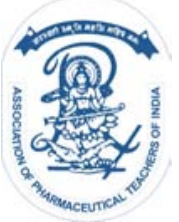

www.ijper.org 
therapeutic value, it has dose dependent nephrotoxicity. Cisplatin induced nephrotoxicity occurs by a complex mechanism. It first gets deposited in renal tissue and causes cytotoxic effect by producing reactive oxygen species. This leads to series of reactions like oxidative stress, inflammation and cell apoptosis. ${ }^{10}$ It has been reported that cisplatin causes acute renal injury after high dose of chemotherapy in $20 \%$ of patients and they developed various degree of renal dysfunction. ${ }^{11}$ There is a high mortality and morbidity among patients with high renal insufficiency. Several therapeutic strategies have been demonstrated to prevent cisplatin induced nephrotoxicity, among that vigorous hydration with normal saline is routinely practiced. But there is no specific treatment for prevention of nephrotoxicity. ${ }^{12}$ Hence there is continuous search for better efficacious drugs to prevent the cisplatin induced nephrotoxicity. The present study aims to standardize the fruit rind of Garcinia pedunculata and to evaluate the nephroprotective efficacy of its aqueous extract.

\section{MATERIALS AND METHODS}

\section{Chemicals}

Cisplatin injection BP (was purchased from KEMOPLAT - Fresenius Kabi Oncology Limited Solan, India). 5,5 dithiobis 2-nitrobenzoic acid, reduced glutathione, thiobarbituric acid, EDTA from HIMEDIA Laboratories Pvt. Limited, Mumbai India. All other chemicals and reagents used were of analytical grade.

\section{Plant material}

The fruits of G. pedunculata were collected from Assam during the month of April 2015. It was authenticated in Pharmacognosy laboratory at SDM Centre for Research in Ayurveda and Allied Sciences, Udupi and the voucher specimen (No. 13100501) has been deposited for further future reference.

\section{Physicochemical standardization}

The powdered fruit rind was standardized as per pharmacopoeial procedures. ${ }^{13}$ The ethanol extract of the fruit rinds was tested for the presence of different phytoconstituents like alkaloid, steroid, flavonoid, tannin, glycoside etc. ${ }^{14}$

\section{Chemical fingerprinting by HPTLC}

One gram of powdered fruit rind was extracted with $10 \mathrm{ml}$ ethanol by cold percolation for $24 \mathrm{~h}$, and then filtered. Five and ten $\mu \mathrm{l}$ of the above samples were applied on a pre-coated silica gel F254 of $0.2 \mathrm{~mm}$ thickness pre-coated on aluminum sheets (Merck, Germany) to a band width of $7 \mathrm{~mm}$ using CAMAG (Switzerland)
Linomat 5 TLC applicator. ${ }^{15}$ The plate was developed in toluene: ethyl acetate: formic acid (10: 2.5: 0.5) in CAMAG glass twin trough chamber previously saturated with mobile phase. The plate was derivatized using vanillin-sulphuric acid (VS), and heated at $105^{\circ} \mathrm{C}$ till the spots appeared. ${ }^{16,17}$ The developed plates were visualized in CAMAG visualizing chamber under short UV, long UV and white light after derivatisation with VS. Following photo-documentation the plates were scanned using CAMAG Scanner 4 under 254 and $366 \mathrm{~nm}$ with the help of CAMAG WinCATS software. $\mathrm{R}_{\mathrm{f}}$ values and densitograms were recorded. ${ }^{18}$

\section{Experimental animals}

Swiss albino mice weighing 30 to $35 \mathrm{~g}$ body weight were used in the present study. Animals were procured from animal house attached to the department of Pharmacology \& Toxicology SDM Centre for research in Ayurveda and Allied Sciences Udupi, India. The Institutional Animal Ethical Committee has approved for experimentation on animals with the reference no SDMCRA/ IAEC/SDM/RC 20. Animals were maintained at standard laboratory conditions such as temperature at 25 to $27^{\circ}$ $\mathrm{C}$, humidity of $50-55 \%$ and $12 \mathrm{~h}$ light and dark cycles. Animals were fed with normal rat diet and water ad libitum.

\section{Extract preparation}

The fruit rinds were shade dried and powdered at SDM Pharmacy Udupi. The powder obtained from a single batch was used throughout the study. Fruit powder of G. pedunculata weighing $500 \mathrm{~g}$ was soaked in 2L of cold distilled water for $24 \mathrm{~h}$ was filtered and concentrated by evaporation. The concentrated extract was used for nephroprotective study.

\section{Acute oral toxicity test}

The acute oral toxicity study was carried out as per OECD guidelines 425 using AOT software. The aqueous extract of fruit rinds of Garcinia pedunculata (AFGP) was made into a suspension in $0.5 \%$ Carboxy methyl cellulose and dosed in the following order 175, 550, and $2000 \mathrm{mg} / \mathrm{kg}$ body weight. After the dosing the animals were observed for 14 days for mortality. The $\mathrm{LD}_{50}$ was determined using AOT software.

\section{Nephrotoxicity study}

After a week of adaptation, mice were divided into four different groups with six mice in each group. Normal control and cisplatin control were treated with $0.5 \% \mathrm{CMC}$ at dose of $0.5 \mathrm{ml} / 100 \mathrm{~g}$ body weight. Group III \& IV were treated with AFGP at a dose of $200 \mathrm{mg} \& 400 \mathrm{mg} / \mathrm{kg}$ body weight for 10 consecutive days. Cisplatin was dissolved in isotonic saline at a concentration of $2 \mathrm{mg} / \mathrm{ml}$. 
On $7^{\text {th }}$ day, an hour after group specific drugs administration, cisplatin $20 \mathrm{mg} / \mathrm{kg}$ was injected intraperitoneal to animals in the cisplatin and test drug groups. On $10^{\text {th }}$ day (72h after cisplatin injection) an hour after last dose of treatment, blood was collected from retro-orbital plexus and animals were sacrificed. ${ }^{19}$

\section{Measurement of renal function}

Blood was collected from retro-orbital plexus after $72 \mathrm{~h}$ of cisplatin injection and centrifuged at $2000 \mathrm{x} \mathrm{g}$ for 5 min. Serum was separated and stored at $-20^{\circ} \mathrm{C}$ until analysis. Serum urea and creatinine level were measured by commercially available kit (Liquicheck AGAPPE Diagnostics LTD) using autoanalyzer (ROCHE 9180 ANALYSER).

\section{Renal histology}

The excised kidney tissues were immediately placed in $10 \%$ formalin. Histology of kidney tissue was conducted by following standard protocol. ${ }^{20}$ The tissues were embedded in paraffin wax and using microtome $8 \mu \mathrm{m}$ thickness sections were taken. The sections were stained with eosin and haematoxyline. The microscopic observations were made using light microscope and photomicrographs of same were taken using digital camera attached to trinocular microscope (ZEISS, Germany).

\section{Assessment of antioxidant parameters}

The tissue homogenate was prepared in phosphate buffer saline $\mathrm{pH} 7.4$ and centrifuged at $4^{\circ} \mathrm{C}$. The clear supernatant was collected and stored at $-20^{\circ} \mathrm{C}$. The supernatant was used for estimating catalase activity, glutathione peroxidase activity and lipid peroxidation using standard protocol.

\section{Determination of catalase activity}

The catalase activity in kidney tissue homogenate was measured according to the procedure of Sinha (1972). ${ }^{21}$ The tissue homogenate $(1 \mathrm{ml})$ was added to test tube containing $5 \mathrm{ml}$ of phosphate buffer. To this added $4 \mathrm{ml}$ of $0.2 \mathrm{M} \mathrm{H}_{2} \mathrm{O}_{2}$ in phosphate buffer and time was noted. Exactly after $180 \mathrm{sec}, 1 \mathrm{ml}$ of reaction mixture was taken in $2 \mathrm{ml}$ of dichromate acetic acid and kept in boiling water bath for $10 \mathrm{~min}$. Test tubes were cooled and absorbance was taken at $570 \mathrm{~nm}$ against reagent blank. The catalase activity in tissue was expressed as $\mu$ moles $\mathrm{H}_{2} \mathrm{O}_{2}$ consumed / $\mathrm{mg}$ protein/min.

\section{Determination of glutathione peroxidase}

The level of glutathione peroxidase in the tissue homogenate was measured according to the method of Rotruck. The tissue homogenate $(0.2 \mathrm{ml})$ was added to the test tube containing $0.2 \mathrm{ml}$ of EDTA, sodium azide, reduced glutathione, hydrogen peroxide and added $0.4 \mathrm{ml}$ of buffer mixed well and incubated at $37^{\circ} \mathrm{C}$ for $10 \mathrm{~min}$. The reaction was arrested by adding $0.5 \mathrm{ml}$ of TCA and centrifuged. The supernatant $(0.5 \mathrm{ml})$ was pipette into test tube containing $4 \mathrm{ml}$ of disodium phosphate and $0.5 \mathrm{ml}$ of DTNB. The colour developed was read at $420 \mathrm{~nm}$ immediately and standard also treated in the similar manner. The level of glutathione peroxidase was expressed as $\mu$ moles of glutathione utilized $/ \mathrm{mg}$ protein $/ \mathrm{min}$ at $37^{\circ} \mathrm{C}^{22}$

\section{Determination of lipid peroxidation}

The lipid peroxidation was determined by measuring the MDA using thiobarbituric acid test. ${ }^{23}$ Tissue homogenate $(0.1 \mathrm{ml})$ was taken in a test tube containing 0.2 $\mathrm{ml}$ of $0.1 \%$ SDS, $1.5 \mathrm{ml}$ of $20 \%$ acetic acid and $1.5 \mathrm{ml}$ of $0.8 \mathrm{~N}$ aqueous solution of TBA. The volume of reaction mixture was made to $4 \mathrm{ml}$ by adding distilled water and heated at $95^{\circ} \mathrm{C}$ for $60 \mathrm{~min}$. The reaction mixture was allowed to cool and $1 \mathrm{ml}$ of distilled water, $5 \mathrm{ml}$ of mixture of $n$-butanol and pyridine $(15: 1 \mathrm{v} / \mathrm{v})$ were shaken well. Finally centrifuged at $4000 \mathrm{rpm}$ for $10 \mathrm{~min}$ and absorbance was measured at $532 \mathrm{~nm}$. The standard malondialdehyde was also processed in the same manner and level of lipid peroxidation was expressed as $\mu$ moles of MDA formed /g of wet tissue.

\section{Statistical analysis}

The results were expressed as Mean \pm SEM and analyzed by one way ANOVA followed by Dunnet's multiple ' $t$ ' test using Graph Pad Prism 3. p <0.05 was considered as statistically significant.

\section{RESULTS}

The fruits of G. pedunculata were large, green in colour, which becomes yellow when ripened (Figure 1a-b). It has a shiny smooth appearance. They weigh about $50 \mathrm{~g}$ with a measurement of $7-8 \times 25-29 \mathrm{~cm}$. Fruit was covered by a thick skin; inside aril is succulent or pulpy. Each fruit has 4-8 seeds seen embedded in a fleshy pulp, which was slimy and has the medicinal value (Figure 1c-d). The sundried longitudinally cut slices of the fruit rind are flattened, flexible, arcuate, the outer pericarp does not shrink unlike inner side, surface uneven, longitudinally wrinkled, bordered with incurved thick margin, corrugated at places and with pointed terminals, varies in length 2 to $5 \mathrm{~mm}$ in thickness, light coffee brown to black in colour, taste sour, odour characteristic (Figure 1e).

TS of the rind shows an outermost layer of epicarp, consisting of tangentially running isodiametric cells embedded with stomata and covered with thin cuticle, 

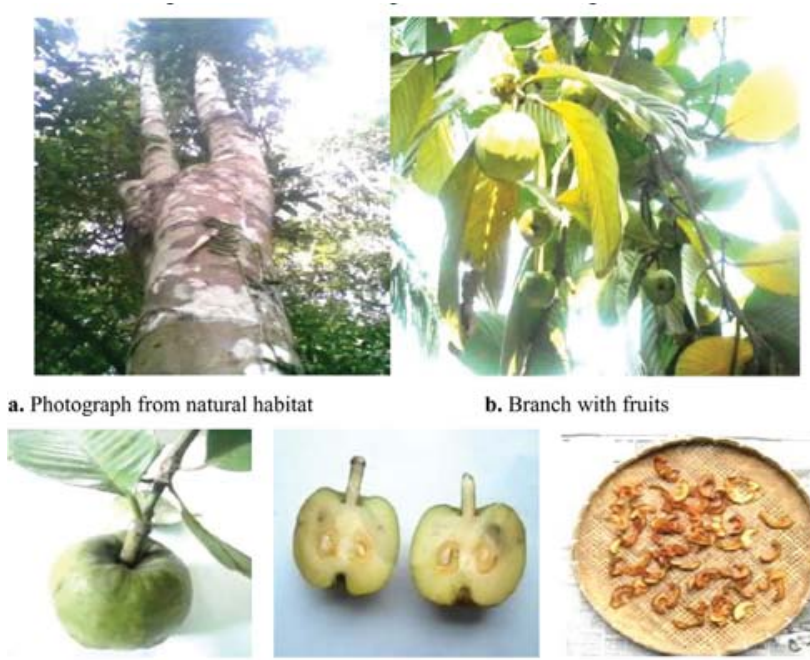

b. Branch with fruits
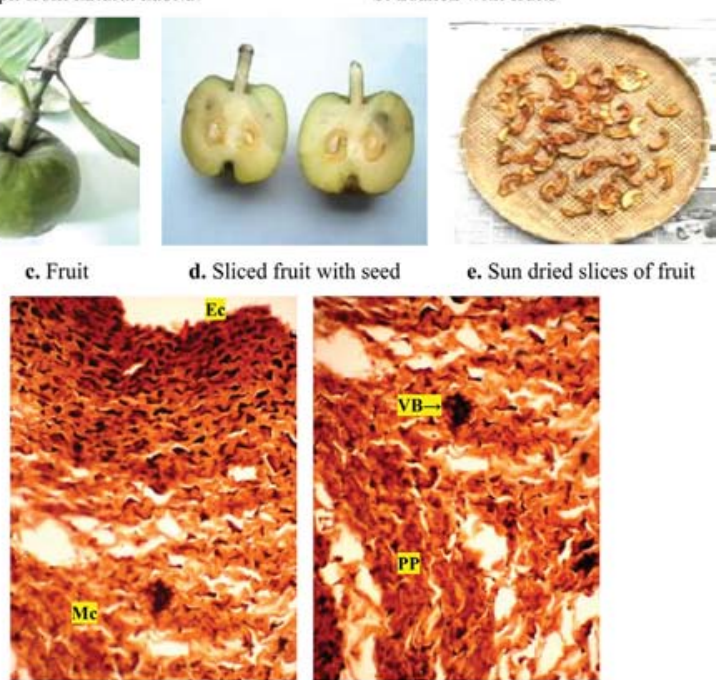

f. T.S of fruit pericarp

Figure 1: Macro-microscopic features of Garcinia pedunculata a. Photograph from natural habitat, b. Branch with fruits, c. Fruit, d. Sliced fruit with seeds, e. Sun dried slices of fruit, f. T.S. of fruit pericarp

at places it gets torn out exposing the inner tissue of hypodermis in mature fruit. Hypodermis is composed of several rows of compactly arranged, tangentially elongated, thick-walled cells embedded with dark brown contents, getting obliterated at places and forming narrow irregular elongated cavities, the outer mesocarp region consisting of loosely arranged tangentially elongated parenchymatous cells few loaded with starch grains, traversed with narrow bands of collapsed cells and oleo-resin ducts underneath this, followed by inner mesocarp zone embedded with rows of fibrovascular bundles, most of its cells being collapsed and compactly arranged; endocarp is inconspicuous (Figure 1f-g).

Powder microscopy showed few oval to circular simple starch grains, yellowish brown resinous matter scattered as such throughout or embedded in the parenchymatous cells, epidermis of pericarp in surface view embedded with stomata, fragments of spiral vessels, fragments of sclerieds from the endocarp region, and fragments inner and outer mesocarp cells (Figure 2a-1).

The values of the physico-chemical constants such as foreign matter, loss on drying, $\mathrm{pH}$, ash values and
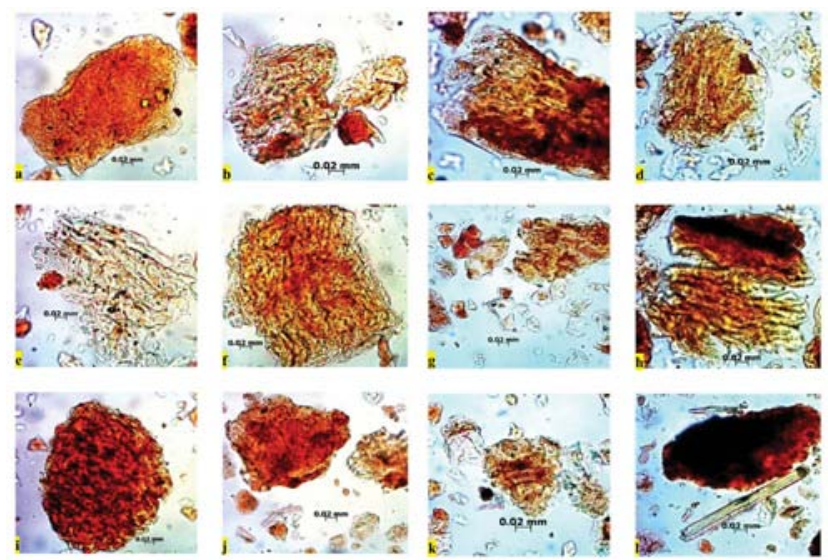

Figure 2: Powder microscopy of Garcinia pedunculata fruit rind

a. epicarp in surface view; b-e. mesocarp parenchyma having simple starch grains; f. outer mesocarp cells; g. fragmented pulp parenchyma; h. inner mesocarp cells; i. outer mesocarp cells; j. pitted vessel associated with phloem; $k$. spiral vessel from fragment of vascular bundle; I. cell with coloured content

extractive values of fruit rind of $G$. pedunculata were estimated in the study. The fruit rind was found to be free from any foreign matter such as insects, moulds, animal faecal matter and other contaminants like sand, stone and extraneous materials. The loss on drying result was found to be $36.67 \% \mathrm{w} / \mathrm{w}$ indicating appreciable quantity of water. $\mathrm{pH}$ value of $10 \%$ aqueous solution was determined to be 1.75 indicating highly acidic nature of the fruit rind. Total ash was $11.50 \% \mathrm{w} / \mathrm{w}$, acid insoluble ash $0.75 \% \mathrm{w} / \mathrm{w}$ and water soluble ash $0.37 \% \mathrm{w} / \mathrm{w}$ indicated the inorganic proportion of the fruit rind. Water, ethanol and chloroform soluble extractive value were $41.36,12.40$ and $0.80 \% \mathrm{w} / \mathrm{w}$ respectively. Heavy metals like $\mathrm{Pb}, \mathrm{Cd}$, As and $\mathrm{Hg}$ were found to be well within the limit and the fresh dried raw drug showed no colonies of microbes (Table 1).

The qualitative phytochemical screening of the fruit rind using water, ethanol and chloroform extracts revealed the presence of carbohydrates/sugars/glycosides, phenols, saponins and carboxylic acid in water and methanol extracts only, while protein, tannin, anthocyanin, flavanoids, phenols, steroids and alkaloids were absent in all the extracts tested (Table 2).

HPTLC finger print profile of ethanol extract has been documented using suitable solvent system. TLC photo-documentation of ethanol extract under short UV showed 6 spots, under long UV there were 7 spots and under white light after derivatisation with vanillin sulphuric acid showed 6 spots with diagnostic $R_{\mathrm{f}}$ values (Table 3 and Figure $3 a-c)$. On densitometric scan of the 
Table 1: Physicochemical constants, heavy metal and microbial load of fruit rind of Garcinia pedunculata

\begin{tabular}{|c|c|}
\hline Parameters & Result \% w/w \\
\hline Foreign matter & Nil \\
\hline Loss on drying at $110^{\circ} \mathrm{C}$ & 36.67 \\
\hline $\mathrm{pH}$ & 1.75 \\
\hline Total ash & 11.5 \\
\hline Acid insoluble ash & 0.75 \\
\hline Water soluble ash & 0.37 \\
\hline Water soluble extractive & 41.36 \\
\hline Alcohol soluble extractive & 12.4 \\
\hline Chloroform soluble extractive & 0.80 \\
\hline Volatile oil & $\mathrm{Nil}$ \\
\hline $\mathrm{Pb}$ & $0.4 \mathrm{ppm}$ \\
\hline $\mathrm{Cd}$ & $<0.1 \mathrm{ppm}$ \\
\hline As & $0.1 \mathrm{ppm}$ \\
\hline $\mathrm{Hg}$ & $0.9 \mathrm{ppm}$ \\
\hline Total viable microbial count & Nil CFU \\
\hline
\end{tabular}

CFU, colony forming units

Table 2: Qualitative phytochemical analysis of different extracts of fruit rind of Garcinia pedunculata

\begin{tabular}{|c|c|c|c|}
\hline Phytochemical & $\begin{array}{c}\text { Aqueous } \\
\text { extract }\end{array}$ & $\begin{array}{c}\text { Ethanol } \\
\text { extract }\end{array}$ & $\begin{array}{c}\text { Chloroform } \\
\text { extract }\end{array}$ \\
\hline Proteins & -- & -- & -- \\
\hline Carbohydrates & + & + & -- \\
\hline Tannins & -- & -- & -- \\
\hline Anthrocyanins & -- & -- & -- \\
\hline Sugars/Glycosides & + & + & -- \\
\hline Saponins & + & + & -- \\
\hline Flavanoids & -- & -- & -- \\
\hline Phenols & + & + & -- \\
\hline Steroids & -- & -- & -- \\
\hline Alkaloids & -- & -- & -- \\
\hline Carboxylic acids & + & + & -- \\
\hline
\end{tabular}

same plates under $254 \mathrm{~nm}$ and $366 \mathrm{~nm} 10$ and 6 peaks were detected respectively (Figure $3 \mathrm{~d}-\mathrm{e}$ ).

Acute oral toxicity study did not revealed mortality in any dose up to $2,000 \mathrm{mg} / \mathrm{kg}$ of aqueous extract of fruits of G. pedunculata. This indicates the $\mathrm{LD}_{50}$ of AFGP is more than $2,000 \mathrm{mg} / \mathrm{kg}$ and hence $1 / 5^{\text {th }}$ and $1 / 10^{\text {th }}$ of $\mathrm{LD}_{50}$ dose was selected for the present nephroprotective study. The renal damage caused by single intraperitonial injection of cisplatin $20 \mathrm{mg} / \mathrm{kg}$ was assessed by biochemical and

\section{Table 3: $\mathbf{R}_{f}$ value of ethanol extract of fruit rind of} Garcinia pedunculata

\begin{tabular}{|c|c|c|}
\hline Under short UV & Under long UV & $\begin{array}{c}\text { Post } \\
\text { derivatisation }\end{array}$ \\
\hline 0.06 (Light Green) & 0.06 (Violet) & - \\
\hline- & - & 0.09 (Light Violet) \\
\hline 0.11 (Light Green) & 0.11 (Light Violet) & - \\
\hline- & - & 0.13 (Light Violet) \\
\hline 0.19 (Green) & 0.19 (Light Violet) & 0.19 (Violet) \\
\hline 0.24 (Light Green) & - & - \\
\hline 0.34 (Light Green) & 0.34 (Light Violet) & - \\
\hline- & - & 0.36 (Light Violet) \\
\hline 0.51 (Light Green) & 0.51 (Light Violet) & - \\
\hline- & 0.60 (Violet) & - \\
\hline- & - & 0.64 (Violet) \\
\hline- & 0.76 (Violet) & 0.76 (Violet) \\
\hline
\end{tabular}

Table 4: Effect of aqueous extract of fruit rind of Garcinia pedunculata on serum biochemical parameters in cisplatin induced nephrotoxicity

\begin{tabular}{|c|c|c|}
\hline Group & Urea $(\mathbf{m g} / \mathbf{d l})$ & Creatinine $(\mathbf{m g} / \mathbf{d l})$ \\
\hline Normal control & $40.57 \pm 1.3$ & $0.66 \pm 0.03$ \\
\hline Cisplatin control & $99.5 \pm 10.02^{@ @ ~}$ & $2 \pm 0.65 @ @$ \\
\hline $\begin{array}{c}\text { AFGP 200 mg/kg + } \\
\text { Cisplatin }\end{array}$ & $44.6 \pm 8.9^{\# \#}$ & $0.49 \pm 0.034^{\# \#}$ \\
\hline $\begin{array}{c}\text { AFGP 400 mg/kg + } \\
\text { Cisplatin }\end{array}$ & $53.42 \pm 13.12^{\# \#}$ & $0.56 \pm 0.05^{\#}$ \\
\hline
\end{tabular}

Data expressed as Mean $\pm \mathrm{SEM}, * * \mathrm{P}<0.01$, @ in comparison to normal control group, \#\#p<0.01 in co-mparison to cisplatin control.

AFGP - Aqueous extract of fruit rind of Garcinia pedunculata.

antioxidant parameters such as serum urea, creatinine and estimation of catalase, glutathione peroxidase and lipid peroxidation. Cisplatin control group has shown significant increase in the serum urea and creatinine level as compared to the normal control group. The cisplatin induced elevation in the serum urea and creatinine were significantly reversed by treatment of AFGP (Table 4). Single intraperitoneal injection of cisplatin significantly increased lipid peroxidation as compared to normal control group. Cisplatin induced elevation in lipid peroxidation was considerably reversed by AFGP administered at both the doses. There was no change in the catalase activity but there was significant increase in the glutathione peroxidase enzyme level in AFGP administered at higher dose level as compared to cisplatin control (Table 5).

Histopathological examination of sections of kidney from normal control mice exhibited normal cytoarchitecture in both cortical and medullary regions. No remarkable changes could be seen in glomeruli or convoluted 
Table 5: Effect of aqueous extract of fruit rind of Garcinia pedunculata on antioxidant parameters in cisplatin induced nephrotoxicity

\begin{tabular}{|c|c|c|c|}
\hline Group & Catalase & Glutathione peroxidase & Lipid peroxidation \\
\hline Normal control & $3082.75 \pm 823.75$ & $14 \pm 0.6$ & $9768 \pm 451.3$ \\
\hline Cisplatin control & $2589.24 \pm 285.47$ & $14.54 \pm 2.7$ & $56154 \pm 1344.3^{@}$ \\
\hline AFGP $200 \mathrm{mg} / \mathrm{kg}+$ Cisplatin & $2660.62 \pm 160.6$ & $19.24 \pm 1.64$ & $23820 \pm 2075.7$ \\
\hline AFGP 400 mg/kg + Cisplatin & $2284.57 \pm 123.54$ & $21.54 \pm 1.24^{\#}$ & $30765.2 \pm 2403.4$ \\
\hline
\end{tabular}

Data expressed as Mean $\pm \mathrm{SEM}, * * \mathrm{P}<0.01$, @ in comparison to normal control group, ${ }^{1} \mu \mathrm{moles} / \mathrm{min} / \mathrm{mg}$ protein; ${ }^{2} \mu$ moles of glutathione/mg protein for $10 \mathrm{mi} 58 \mathrm{n} ;{ }^{3} \mu$ moles of MDA formed $/ \mathrm{g}$ wet tissue. AFGP - Aqueous extract of fruit rind of Garcinia pedunculata

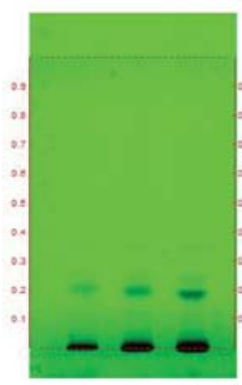

a. Under short UV

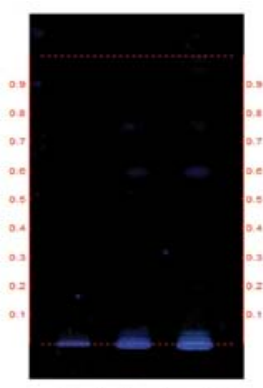

b. Under long UV Track 1-2 2 l; $2-4 \mu \mathrm{l} ; 3-6 \mu \mathrm{l}$

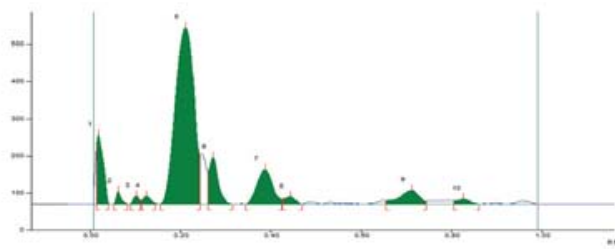

d. Densitometric scan at $254 \mathrm{~nm}$

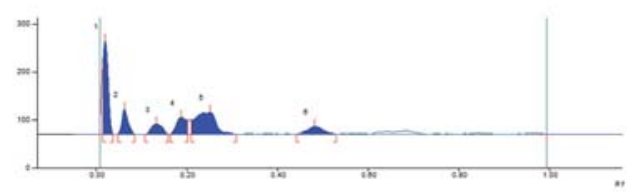

e: Densitometric scan at $366 \mathrm{~nm}$

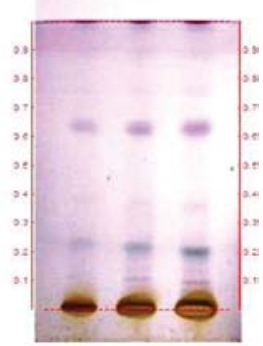

c. Post derivatisation

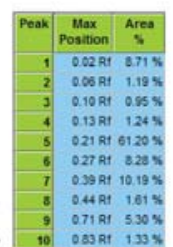

$07181530 \%$

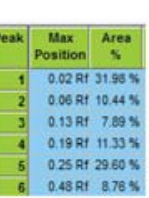

Figure 3: HPTLC fingerprinting of ethanol extract of fruit rind of Garcinia pedunculata

a. Under short UV b. Under long UV c. Post derivitisation

d. Densitometric scan at $254 \mathrm{~nm}$ e. Densitometric scan at $366 \mathrm{~nm}$
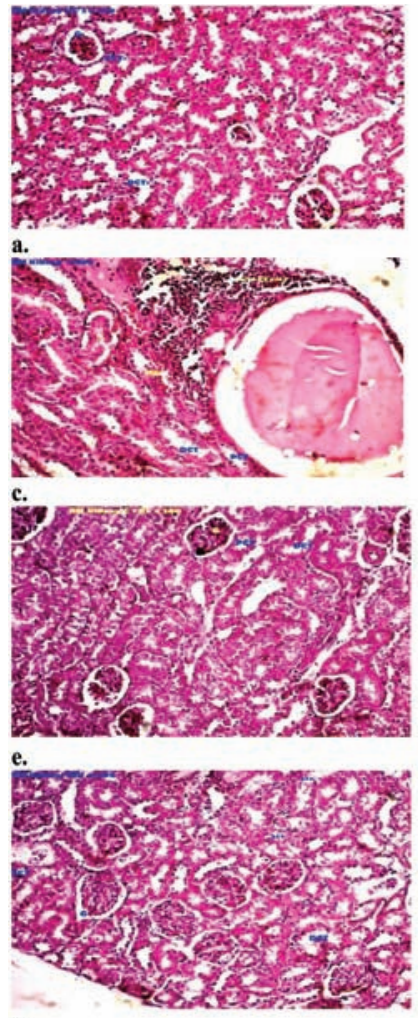

g.
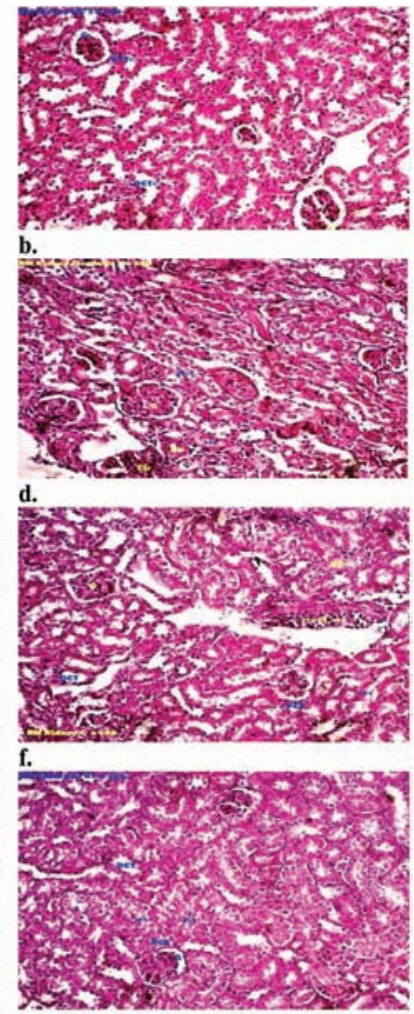

h.

Figure 4: Photomicrograph representative of kidney sections a \& b. normal control group; c \& d. cisplatin control group e \& f. AFGP administered $200 \mathrm{mg} / \mathrm{kg}$ + cisplatin; g \& h. AFGP administered $400 \mathrm{mg} / \mathrm{kg}+$ cisplatin. [magnification-200x] AFGP - Aqueous extract of the fruit rind of Garcinia pedunculata, PCT - Proximal convoluted tubules, DCT - Distal convoluted tubules, Dil - Dilatation, G - Glomerulus

\section{DISCUSSION}

mice showed necrotic changes in the tubular epithelium, vacuolization oedema in the interstial tissue and focal cell infiltration was also observed. However, the medullalry region was not affected in remarkable manner. Sections obtained from AFGP treated mice showed only mild to moderate degenerative changes in comparison to the cisplatin control group. Vacuolization, frequency of focal cell infiltration and necrotic changes were much less in the AFGP administered group (Figure 4a-h).

The process of finding out of standards of herbal drugs is an important aspect of medicinal plant research for establishing identity of plant drugs. To obtain standards on quality specifications of herbs, botanical description along with chemical composition, analytical and phytochemical examination is required. All the materials intended for medicinal purposes must undergo assessment of quality standards employing all possible means of botanical or chemical analyses. Standardisation of herbal 
medicines is the process of developing and agreeing upon technical standards. ${ }^{24}$ Macro-microscopic features are important quality determining tests for herbal drugs while confirming botanical source in dried form. The macro-microscopic of pericarp of G. pedunculata has been documented in the current study which has shown usual features of fruits, while multi-layered epidermal and hypodermal cells with contents can be used as diagnostic microscopic features of the drug. Physicochemical composition by Pharmacopoeia tests are employed normally for checking quality of herbal drugs as per international standards. The results obtained will infer quality in terms of its moisture content, ash content, extractive values which are widely used as standards for quality of herbal drugs. The constants obtained in the current study will serve as an indication of chemical quality of $G$. pedunculata for quality control and standardisation of this drug in further researches. Every plant acts on a biological system due to presence of certain phytochemicals, therefore it is essential to evaluate potency of an herbal drug in terms of its chemical compositions. A preliminary qualitative phytochemical examination by colour tests indicated presence of carbohydrates/ glycosides and saponins. (-)-Hydroxy citric acid is the reported active principle of this species which may be responsible for the observed pharmacological actions. Botanical drugs can be effectively fingerprinted using high performance thin layer chromatography (HPTLC). It is an efficient and cost effective way of analysing a broad number of chemical compositional variations qualitatively as well as quantitatively. TLC identity test is a part of every herbal monograph of international standards including FDAs. HPTLC profile of the G. pedunculata obtained in the current study can be used as a quality indicating fingerprint.

Cisplatin is an important cytotoxic agent used in the treatment of testicular, head \& neck and cervical cancer. Despites its wide spread use in different solid tumors, its side effect on normal tissues like kidney, liver and neuronal tissues limits its use. ${ }^{25}$ There are many strategies used to prevent its nephrotoxicity such as development of novel platinum based chemotherapeutic agent which causes less side effect on normal tissues such as carboplatin, hydration during cisplatin treatment, use of antioxidants, suppression of inflammatory process, inhibition of cell death pathways, decreased cisplatin uptake by renal cells etc. ${ }^{26-28}$

The present study was designed to investigate renoprotective effect of aqueous extract of fruits of Garcinia pedunculata against cisplatin induced nephrotoxicity.

It has been reported that cisplatin after single intraperitoneal administration can readily cross the cell membrane and gets accumulated in the renal tubular cells either through passive diffusion or by facilitated diffusion. After entering into the renal tubular cells it can trigger the signaling pathways that can promote cell death. Meanwhile it can also induce inflammatory cytokines such as TNF- $\alpha$ and cause inflammatory response. Other possible mechanism is, it can cause ischemic vascular damage and produce renal tubular damage. These changes collectively effects on drastic reduction in the glomerular filtration rate and pathological changes in the cytoarchitecture of renal tissue that leads to acute renal failure. ${ }^{29-31}$

In the present study cisplatin administration caused significant elevation in the serum urea and creatinine level as compared to normal control. This indicates the cisplatin administered at $20 \mathrm{mg} / \mathrm{kg}$ intraperitoneal injection readily caused renal toxicity. These cisplatin induced nephrotoxicity was significantly reversed by co administration of two different dose levels of AFGP. Thus we can confirm that test drug has renoprotective activity based on biochemical results.

The role of reactive oxygen species and free radicals in cisplatin induced nephrotoxicity has been reported in previous works. These free radicals and ROS were produced via xanthine-xanthine oxidative system, mitochondria and nicotinamide adenine dinucleotide phosphate (NADPH) oxidase in the cells in the presence of cisplatin and its metabolites. It can directly act on cellular components including lipids, proteins and DNA. ${ }^{32-33}$

Cisplatin and its metabolites can readily cause severe oxidative stress in the renal tissue. This can be evident from the increased lipid peroxidation and decreased defensive antioxidant enzymes such as catalase and glutathione peroxidase. In the present study there was significant elevation in MDA levels which indicates the lipid peroxidation in the cisplatin control as compared to the normal control. AFGP administered at 2 different dose levels has shown reduction in the lipid peroxidation and significant increase in the glutathione peroxidase as compared to the cisplatin control. Thus the observed renoprotective effect of the test drug could be due to its general cytoprotective activity and readily prevented the ischemic damage caused by acute cisplatin toxicity. The histopathology of kidney sections from cisplatin control exhibited necrotic changes in the tubular epithelium, edematous changes in the interstitial tissue and focal cell infiltration. Whereas the test drug administered at two dose levels has shown mild to moderate toxic changes as compared to cisplatin control and vacuolization, frequency of focal cell infiltration and necrotic changes were much less in the test extract administered group. 
Thus histopathalogical findings support the generalized cytoprotective effect of test drug.

\section{CONCLUSION}

The study concludes that the quality standardized fruit of Garcinia pedunculata has nephroprotective activity. The results of the study can be used for developing standards for this drug and for development of new drugs for nephroprotection.

\section{AKNOWLEDGMENT}

We thank the Registrar, Research Director and Dean, Saveetha University, Chennai for their constant motivation to carry out the research activities. The last four authors would like to extend their sincere appreciation to the Deanship of Scientific Research, Research Centre, College of Science, King Saud University, Riyadh, Saudi Arabia.

\section{CONFLICT OF INTEREST}

There is no conflict of interest from any of our coauthors.

\section{ABBREVIATION USED}

FRGP: Fruit rind of Garcinia pedunculata; HPTLC: High performance thin layer chromatography; AFGP: Aqueous extract of the fruit rind of Garcinia pedunculata; OECD: Organisation for Economic Co-operation and Development.

\section{REFERENCES}

1. Kagyung R, Gajurel PR, Rethy P, Singh B. Ethnomedicinal plants used for gastro-intestinal diseases by Adi tribes of Dehang-Debang Biosphere Reserve in Arunachal Pradesh.

2. Jayaprakasha GK, Negi PS, Jena BS. Antioxidative and antimutagenic activities of the extracts from the rinds of Garcinia pedunculata. Innovative Food Science \& Emerging Technologies. 2006;7(3):246-50. https://doi. org/10.1016/j.ifset.2006.01.001

3. Sahu A, Das B, Chatterjee A. Polyisoprenylated benzophenones from Garcinia pedunculata. Phytochemistry. 1989;28(4):1233-5. https://doi. org/10.1016/0031-9422(89)80216-X.

4. Jayaprakasha GK, Jena BS, Sakariah KK. Improved liquid chromatographic method for determination of organic acids in leaves, pulp, fruits, and rinds of Garcinia. Journal of AOAC International. 2003;86(5):1063-8. PMid:14632411.

5. Negi PS, Jayaprakasha GK, Jena BS. Antibacterial activity of the extracts from the fruit rinds of Garcinia cowa and Garcinia pedunculata against food borne pathogens and spoilage bacteria. LWT-Food Science and Technology. 2008;41(10):1857-61. https://doi.org/10.1016/j.lwt.2008.02.009.

6. Ravi M, Madhan C, Ravishankar B. Hepatoprotective activity of fruits extract of Garcinia pedunculata. Bangladesh J of Pharmacol 2014a;9:4-8.

7. Mundugaru R, Joy F, Shrinidhi R, Das L, Sudhakara RB. Anti-inflammatory activity of aqueous extract of fruits of Garcinia pedunculata in experimental animals. Am J Pharma Tech Res. 2014;4(3).
8. Ravi M, Senthilkumar S, Padmaja U, Sudhakara B. Cardio protective activity of fruits extract of Garcinia pedunculata. Bangladesh J of Pharmacol 2016;11:5-9.

9. Pabla N, Dong Z. Cisplatin nephrotoxicity: mechanisms and renoprotective strategies. Kidney International. 2008;73(9):994-1007. https://doi. org/10.1038/sj.ki.5002786; PMid:18272962.

10. Yokoo S, Yonezawa A, Masuda S, Fukatsu A, Katsura T, Inui KI. Differential contribution of organic cation transporters, OCT2 and MATE1, in platinum agent-induced nephrotoxicity. Biochemical Pharmacology. 2007;74(3):477-87. https://doi.org/10.1016/j.bcp.2007.03.004; PMid:17582384.

11. Yao X, Panichpisal K, Kurtzman N, Nugent K. Cisplatin nephrotoxicity: a review. American Journal of the Medical Sciences. 2007;334(2):115-24. https://doi.org/10.1097/MAJ.0b013e31812dfe1e; PMid:17700201.

12. Launay-Vacher V, Rey JB, Isnard-Bagnis C, Deray G, Daouphars M. Prevention of cisplatin nephrotoxicity: state of the art and recommendations from the European Society of Clinical Pharmacy Special Interest Group on Cancer Care. Cancer chemotherapy and pharmacology. 2008;61(6):903-9. https://doi.org/10.1007/s00280-008-0711-0; PMid:18317762.

13. Quality control methods for medicinal plant materials. Geneva: World Health Organiation; 1998.

14. Sunil Kumar KN, Sangeetha B, Suchitra P, Ravishankar B, Yashovarma B. Pharmacognosy and quality characterization of Balanites aegyptiaca (L.) Delile fruits. Indian Journal of Natural Products and Resources (IJNPR) [Formerly Natural Product Radiance (NPR)]. 2016;7(1):40-50.

15. Sethi PD. High Performance Thin Layer Chromatography. New Delhi: CBS Publishers and Distributors; 1996.

16. Stahl E. Thin layer Chromatography: A laboratory hand book. Berlin Heidelberg: Springer-Verlag; 1969. https://doi.org/10.1007/978-3-642-88488-7.

17. Wagner H, Bladt S. Plant Drug Analysis. 2nd ed. Berlin Hiedelber: SpringerVerlag; 1996. https://doi.org/10.1007/978-3-642-00574-9.

18. Kumar KS, Ravishankar B, Yashovarma B, Rajakrishnan R, Thomas J. Development of quality standards of medicinal mistletoe-Helicanthes elastica (Desr.) Danser employing Pharmacopoeial procedures. Saudi Journal of Biological Sciences. 2016;23(6):674-86. https://doi.org/10.1016/j. sjbs.2016.02.023; PMid:27872562 PMCid:PMC5109044.

19. Megyesi J, Safirstein RL, Price PM. Induction of p21WAF1/CIP1/SDI1 in kidney tubule cells affects the course of cisplatin-induced acute renal failure. Journal of Clinical Investigation. 1998;101(4):777. https://doi.org/10.1172/ JCl1497; PMid:9466972 PMCid:PMC508625.

20. Bancroft JD, Gamble M. Theory and practice of histological techniques. $5^{\text {th }}$ ed. Edinburgh: Churchill Livingstone: 2002.

21. Sinha AK. Colorimetric assay of catalase. Analytical biochemistry. 1972;47(2):389-94. https://doi.org/10.1016/0003-2697(72)90132-7.

22. Rotruck JT, Pope AL, Ganther HE, Swanson AB, Hafeman DG, Hoekstra W. Selenium: biochemical role as a component of glutathione peroxidase. Science. 1973;179(4073):588-90. https://doi.org/10.1126/ science.179.4073.588; PMid:4686466.

23. Ohkawa $\mathrm{H}$, Ohishi $\mathrm{N}$, Yagi K. Assay for lipid peroxides in animal tissues by thiobarbituric acid reaction. Analytical Biochemistry. 1979;95(2):351-8. https://doi.org/10.1016/0003-2697(79)90738-3.

24. Kunle OF, Egharevba $\mathrm{HO}$, Ahmadu PO. Standardization of herbal medicines - A review. Int J Biodivers Conserv 2012;4:101-12. https://doi.org/10.5897/ IJBC11.163.

25. Kuhad A, Tirkey N, Pilkhwal S, Chopra K. Renoprotective effect of Spirulina fusiformis on cisplatin-induced oxidative stress and renal dysfunction in rats. Renal Failure. 2006;28(3):247-54. https://doi. org/10.1080/08860220600580399; PMid:16703798.

26. Bajorin DF, Bosl GJ, Alcock NW, Niedzwiecki D, Gallina E, et al. Pharmacokinetics of cis-diamminedichloroplatinum (II) after administration in hypertonic saline. Cancer Research. 1986;46(11):5969-72. PMid:3756934

27. Cornelison TL, Reed E. Nephrotoxicity and hydration management for cisplatin, carboplatin, and ormaplatin. Gynecologic Oncology. 1993;50(2):14758. https://doi.org/10.1006/gyno.1993.1184; PMid:8375728.

28. Pasetto LM, D'Andrea MR, Brandes AA, Rossi E, Monfardini S. The development of platinum compounds and their possible combination. Critical Reviews in Oncology/Hematology. 2006;60(1):59-75. https://doi. org/10.1016/j.critrevonc.2006.02.003; PMid:16806960. 
Ramesh G, Reeves WB. TNFR2-mediated apoptosis and necrosis in cisplatininduced acute renal failure. American Journal of Physiology-Renal Physiology. 2003;285(4):F610-8. https://doi.org/10.1152/ajprenal.00101. 2003; PMid:12865254.

30. Ramesh G, Reeves WB. Inflammatory cytokines in acute renal failure. Kidney International. 2004;66:S56-61. https://doi.org/10.1111/j.1523-1755.2004. 09109.x; PMid:15461705.

31. Tsuruya K, Ninomiya T, Tokumoto M, Hirakawa M, Masutani K, et al, lida M. Direct involvement of the receptor-mediated apoptotic pathways in cisplatin- induced renal tubular cell death. Kidney international. 2003;63(1):72-82. https://doi.org/10.1046/j.1523-1755.2003.00709.x; PMid:12472770.

32. Ajith TA, Usha S, Nivitha V. Ascorbic acid and $\alpha$-tocopherol protect anticancer drug cisplatin induced nephrotoxicity in mice: a comparative study. Clinica Chimica Acta. 2007;375(1):82-6. https://doi.org/10.1016/j.cca.2006.06.011; PMid:16889761.

33. Fujieda M, Naruse K, Hamauzu T, Miyazaki E, Hayashi Y, et al. Effect of selenium on Cisplatin-induced nephrotoxicity in rats. Nephron Experimental Nephrology. 2006;104(3):e112-22. https://doi.org/10.1159/000094550; PMid:16837816.

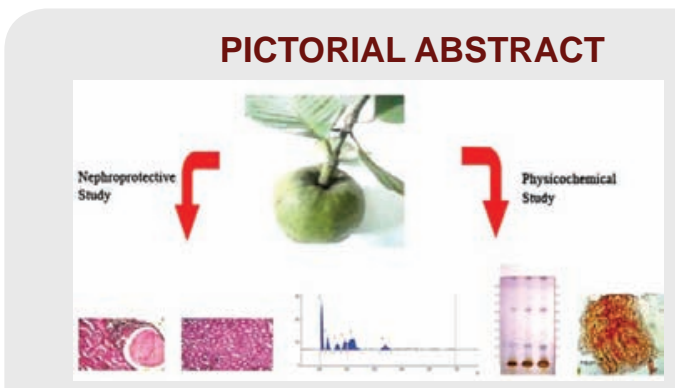

\section{SUMMARY}

The present study was aimed to determine the quality standards for the fruit rind of Garcinia pedunculata and its efficacy as a nephroprotective agent against cisplatin induced nephrotoxicity. Pharmacopoeial tests revealed authenticity and quality indicating standards for the fruit rind. The cisplatin induced nephrotoxic changes in mice were significantly reduced with the administration of the aqueous extract of fruit rind.

\section{About Authors}

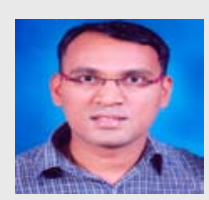

Dr. KN Sunil Kumar is working as Research Officer and Head of Department of Pharmacognosy in Siddha Central Research Institute, Chennai, India. He has completed in M.Sc. Ayu. Medicinal Plants -Pharmacognosy specialization from Gujarat Ayurveda University in 2006 and PhD in Medicinal Plants/Pharmacognosy from University of Madras in 2014. His field of expertise includes Taxonomy, Pharmacognosy, Phytochemistry, Standardization, Quality control, Pharmacology and In vitro assays. He has published 91 research papers in national and international peer reviewed journals in addition to 55 monographs in Quality standards of Indian Medicinal Plants.

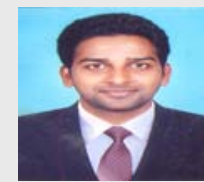

Mr. Ravi Mundugaru is working as Research Officer in Pharmacology \& Toxicology at SDM Ayurveda and Allied Sciences, Udupi, India. He is MSc in Medical Pharmacology from Manipal University, Manipal and persuing PhD from Saveetha University, Chennai. He is investigating AYUSH-EMR projects on safety evaluation of two important Herbo-mineral formulations used in the Ayurvedic practice. He is Author of 30 research papers.

Cite this article: Ravi M, Sivanesan S, Padmaja U, Febin J, SunilKumar KN, Lekshmi R, Alfarhan AH, Thomas J, Rajakrishnan R, Sameh MH. Quality Standardization and Nephroprotective Effect of Garcinia pedunculata Roxb. Fruit rind. Indian J of Pharmaceutical Education and Research. 2017;51(4):713-21. 